\title{
Arts and crafts, decorative and applied arts as a growth driver of educational tourism
}

\author{
Yulia Osipova ${ }^{1 *}$ and Lyudmila Kazmina ${ }^{1}$ \\ ${ }^{1}$ Don State Technical University, 1, Gagarina Sq., 344003, Rostov-on-Don, Russia
}

\begin{abstract}
The present article is concerned with analysis of the current state and prospects for the development of educational tourism in Russia and its regions, fostering the development of educational tourism in Russia.It is emphasized that arts and crafts can become one of the main factors promoting the development of tourism. Authors propose solutions of issues of insufficient including of arts and crafts into touristic programs and routs. Special attention is paid to state policy in regard to preserving and popularization of arts and crafts of Russia and its regions.
\end{abstract}

\section{Introduction}

Considering general trends of the development of the tourism industry in Russia, the development and arrangement of new culture-oriented touristic programs and routs should become the focus areas of inbound and domestic tourism.

Arts and crafts as the most important part of Russian culture, being the sector of both folk culture and industry, can be a driver in this process. Therefore, tourism is becoming the essential branch in preserving and developing arts and crafts. Arts and crafts, decorative and applied arts are of much interest to modern tourists.

As the years pass, extinction of many nonrecoverable branches of folk culture occurs. Masters part from this life, and new generation never adopted their practice. That is why it is necessary for tourism to become a thread that would connect the coming generation and folk culture.

Today's public education policy focuses on the upbringing of harmonious young people as future builders and defenders of Russia.

The goal of the study is to identify a place and a role of arts and crafts, decorative and applied arts in the development of educational tourism.

Based upon the target goal, the following tasks are to be completed: to identify development factors of educational tourism; to define folk artistic crafts, decorative and applied arts; to estimate legal regulation of preserving and developing folk artistic crafts; to consider the geography of centers of folk artistic crafts in Russia and its regions; to provide insight into mutually rewarding process of the regeneration of arts and crafts and of the development of domestic tourism exemplified by the Rostov region.

\footnotetext{
* Corresponding author: osipova yulia@list.ru
} 


\section{Background and methods}

The concept of this article is based on abstract theorems and proven results of scientific papers of such authors as A. Liu, D.C. Wu [1], who considered the important role of tourism in the development of the regional economy; and Sung-Ta Liu[2], whose papers cover aspects of the development of cultural and educational tourism being the top-priority type of tourism, which promotes the transformation of cultural values into sightseeing attractions.

Prospects for the involvement of cultural heritage in the tourism industry are considered in the papers of E. D.Santa, S. A. Tiatco [3], A. Z. Zakaria, I.H. Salleh, M. S. Abd Rashid [4],W. C.Hunter [5].Experience of the Philippines, Malaysia, and Taiwan.

Studies of M-N. Văidianu, O. Pavel, I-E. Călin [6] cover the issues and prospects of involving the cultural potential of small villages located on the islands of the Danube Delta Biosphere Reserve into the tourism sector.

For this study, the provisions of X. Yu, H. Xu [7], C. Wei, S. Dai, H. Xu, H. Wang [8], considering the problems of involving cultural heritage in the tourist practice of China, were also taken into account.

In the papers of E. Chibir, T. Shirko [9], the cultural potential of Russia in general and of regions in particular is considered not only as a key factor in the development of educational tourism, but also as a starting point for significant economic growth of the country.

It should be noted that one of the key roles in the development of educational tourism is played by folk artistic crafts, decorative and applied arts. It is proved by the provisions of papers of M. Haigh[10].F. Thompson, K. Hannam, K. Petrie[11] argue that artistic trades, arts and crafts often change into souvenir gifts and serve as an additional touristic interest in educational tourism. Such arguments are supported by Z.Shtudiner, G.Klein, M.Zwilling, J. Kantor [12], C. Anastasiadou, S. Vettese [13] in their papers.

Using the concept of "folk artistic crafts, decorative and applied arts", it should be noted that it can be considered as a structural component of the concept of "folklore", which was introduced into scientific use by the English scientist W. J. Tome in 1846. The concept itself, the phenomenon, as well as the study of the role of folklore in the global heritage policy is presented in the papers of B. Klein [14].

The use of folkloristic artwork, folk artistic crafts, decorative and applied arts as a factor of attracting tourist flows and the development of educational tourism is described in the papers of P Hayward, S. Kuwahara [15], T-H. Tsai, C-M Chen [16].

A lot of papers of Russian authors, who consider arts and crafts from the perspective of tourist interest and the tourism industry development, have appeared over the last few years. This vision is reflected in the papers of N.V. Yakovenko [17-18], G.V. Ganshina, N.V. Chaus [19], G.M. Samostroenko [20], M.A. Sarancha, S. L. Yakimova [21].

It should be especially noted that this study uses views on the classification of arts and crafts, which are reflected in the papers of D.A. Amanzholova [22], A.V. Shestakova [23] and V.A. Aleksunin, MA Chernaya [24].

A number of authors believe that it is the development of cultural and educational tourism that makes it possible to counteract tourist seasonality. These attements can be seen in the papers of A. S. Vergori, S. Arima [25].

For the sake of completeness, the authors analyzed the papers on domestic tourism in rural areas of he Rostov region of Kazmina, V.S. Makarenko, V.V. Provotorina, T.N. Shevchenko, $2020[26,27]$. 
In the study, the authors applied such research methods as a descriptive method used to characterize the current prospects for the development of educational tourism; a statistical analysis, including the identification and subsequent analysis of the centers of the main sectors and types of manufacturing, folk artistic crafts, decorative and applied arts; a comparative analysis of the dissemination of folk artistic crafts, decorative and applied arts along the territory of Russia and its regions; a synthesis and classification of locations of folk artistic crafts, decorative and applied arts of the Rostov region, as well as events organized on their basis; a prospective method, used to identify ways to popularize folk artistic crafts, decorative and applied arts of the Rostov region as a growth driver of educational tourism.

\section{Results}

Considering cultural and educational tourism, it can said that it is one of the most stable, promising and demanded segments of the Russian tourist market, both domestic and inbound.

According to the statistics provided by the Federal Agency of Tourism of Russia, cultural and educational tourism ranks second (20\%) in the structure of the domestic tourist flow, trailing only the beach one (38\%).

Analyzing the inbound tourist flow to Russia, it can be said that the cultural and educational goals of tourists are rated at $34 \%$, which is also the second to business purposes of travel $(56 \%)$.

In present-day conditions, domestic cultural and educational tourism is the most promising area of the social and economic development of the country and its territories. This type of tourism holds a high position in the structure of tourist flows. It accounts for a fifth of the domestic tourist flow and a third of inbound tourism. It is important to note that tourism is not only a form of recreation and entertainment, but also a way to gain new knowledge, self-development and self-education.

Practically all regions of the Russian Federation have a huge historical and cultural potential and rich natural and recreational resources. All this potential provides great opportunities for the development of tourism in large and small cities of the Russian Federation.

The main factors in the development of educational tourism are historical and cultural heritage, which is represented by such objects as: archaeological sites; church and civil architecture; technical complexes and structures; social infrastructure; theaters, museums, exhibitions; historical cities; rural settlements; objects of ethnography; arts and crafts; decorative and applied arts.

Arts and crafts allow tourists to be exposed to and join the ethnographic heritage of the region.

One of the main tools to promote the tourist potential in the regions is folk artistic crafts, or more specifically their "market component". Tourism in this context acts as a resource for the preservation and development of trades and crafts in Russia and as a tool for the economic development of the territory.

Today, almost all regions of Russia, including the Rostov region, have their own, sometimes small, but unique folk artistic crafts. Very often, this is what acts as a factorforming potential for the development of educational tourism as a component of a regional tourist product.

Folk artistic crafts not only determine the specifics and promising types of the tourism development, but also influence the formation of priority areas of the investment policy in the region. 
Considering the mechanism for the development of educational tourism by involving folk artistic crafts as objects of tourist interest, each separate region of Russia will need to classify and register them, that will contribute to the formation of a certain image and brand of the territory.

Folk artistic crafts often act as an independent tourist resource of the region and, as a rule, are able to create an attractive, head-turning image of tourist localization quickly and affordably.

The use of the concept "folk artistic crafts, decorative and applied arts" as a structural component of the concept of "folklore" was introduced into scientific use by the English scientist W. J. Tome in 1846.

Table 1. Main areas of folk artistic crafts.

\begin{tabular}{|c|c|c|}
\hline No & Main areas of folk artistic crafts & Main types of creation of handicrafts \\
\hline 1. & $\begin{array}{l}\text { Work of wood and other vegetable } \\
\text { materials }\end{array}$ & $\begin{array}{l}\text { Carving, marquetry, turning, pokerwork, } \\
\text { embossing. }\end{array}$ \\
\hline 2. & Art pottery manufacture & $\begin{array}{l}\text { Chinaware, semiporcelain ware, stoneware, } \\
\text { delftware, majolica, pottery ware }\end{array}$ \\
\hline 3. & Metal art & $\begin{array}{l}\text { Decorative ironwork, cutting-out, metalsmithing, } \\
\text { raising, stamping, casting, filigree, faced cutting, } \\
\text { graving, pickling, oxidizing, enamel plating } \\
\text { (enamel miniature), etc. }\end{array}$ \\
\hline 4. & Jewelry making (handicrafts) & $\begin{array}{l}\text { Jewelry of silver, non-ferrous metals and alloys } \\
\text { (including those with semiprecious stones and } \\
\text { artificial stones). }\end{array}$ \\
\hline 5. & Miniature lacquer painting & $\begin{array}{l}\text { Painting with the use of egg tempera or oil colors } \\
\text { followed by lacquering. }\end{array}$ \\
\hline 6. & Stone carving & $\begin{array}{l}\text { Material (stone) shaping, polished dressing, and } \\
\text { polished finish, which the color and natural } \\
\text { pattern. }\end{array}$ \\
\hline 7. & Bone and horn carving & $\begin{array}{l}\text { Bone and horn carving with the application of } \\
\text { various carving methods:open-work method, relief } \\
\text { sculpture, three-dimensional method, graving. }\end{array}$ \\
\hline 8. & Needlework (handicrafts) & $\begin{array}{l}\text { Various types of hand-embroidery and machine } \\
\text { embroidery in leather, fabric, or felt. }\end{array}$ \\
\hline 9. & Hand lacework & $\begin{array}{l}\text { Hand lacemaking or a combination of hand and } \\
\text { machine lacemaking }\end{array}$ \\
\hline 10. & Hand weaving & Hand weaving \\
\hline 11. & Hand knitting & $\begin{array}{l}\text { Patterned knitting using pins or a knitting machine } \\
\text { followed by hand finishing of patterns. }\end{array}$ \\
\hline 12. & $\begin{array}{l}\text { Hand carpet making and carpet } \\
\text { weaving }\end{array}$ & Carpet making using high-warp looms \\
\hline 13. & Hand textile painting and printing & $\begin{array}{l}\text { Fabric decoration with the application of various } \\
\text { hand techniques:free painting, hot and cold batik, } \\
\text { hand printing, hand block printing. }\end{array}$ \\
\hline 14. & Leather and fur processing. & $\begin{array}{l}\text { Processing of leather and fur using national types } \\
\text { of embroidery and appliqués, both hand-made and } \\
\text { machine-and-hand made. }\end{array}$ \\
\hline
\end{tabular}

The concept itself is quite concise, and a rather deep meaning was put into it, which united both "folk culture" and "folk art". It is argued that the main goal in the study of folklore is considered to be the disclosure of the artistic value of craft items, that is nothing but "folk artistic crafts."

It is known that only in the latter half of the nineteenth century, the concepts of "handicrafts", "artistic handicraft", "folk art" appear in the science of art. 
Table 2. Worldwide renowned centers of folk art.

\begin{tabular}{|c|c|c|c|}
\hline No. & Folk art centers & Location & Type of folk craft \\
\hline 1. & Palekh & the Ivanovo region & Miniature lacquer painting \\
\hline 2. & Kholuy & the Ivanovo region & Miniature lacquer painting \\
\hline 3. & Fedoskino & the Moscow region & Miniature lacquer painting \\
\hline 4. & Semyonov & $\begin{array}{l}\text { the Nizhny Novgorod } \\
\text { region }\end{array}$ & Wood painting and carving \\
\hline 5. & Gorodets & $\begin{array}{l}\text { the Nizhny Novgorod } \\
\text { region }\end{array}$ & $\begin{array}{l}\text { Wood painting and carving, gold } \\
\text { embroidery }\end{array}$ \\
\hline 6. & Bogorodsk & $\begin{array}{l}\text { the Nizhny Novgorod } \\
\text { region }\end{array}$ & Wood painting and carving \\
\hline 7. & Arkhangelsk & the Arkhangelsk region & Wood painting and carving \\
\hline 8. & Torzhok & the Tver region & Gold embroidery \\
\hline 9. & Kholmogory & the Arkhangelsk region & Bone-carving \\
\hline 10. & Uelen & the Chukotka district & Bone-carving \\
\hline 11. & Tobolsk & the Tyumen region & Bone-carving \\
\hline 12. & Veliky Ustyug & the Vologda region & Silverware \\
\hline 13. & Krasnoye Selo & Saint-Petersburg & Silverware \\
\hline 14. & Tula & The Tula Region & Weapon \\
\hline 15. & Zlatoust & the Chelyabinsk region & Weapon \\
\hline 16. & Moscow & the Moscow region & Weapon \\
\hline 17. & Pavlovo & $\begin{array}{l}\text { the Nizhny Novgorod } \\
\text { region }\end{array}$ & Weapon \\
\hline 18. & Vologda & the Vologda region & Lacemaking \\
\hline 19. & Elets & the Lipetsk region & Lacemaking \\
\hline 20. & Mikhaylov & the Ryazan region & Lacemaking \\
\hline 21. & Kadom & the Ryazan region & Lacemaking \\
\hline 22. & Skopin & the Ryazan region & Pottery \\
\hline 23. & Pskov & the Pskov region & Pottery \\
\hline 24. & Yaroslavl & the Yaroslavl region & Pottery \\
\hline 25. & Kirov & the Kirov region & Pottery \\
\hline 26. & Verbilki & the Moscow region & Chinaware \\
\hline 27. & $\begin{array}{ll}\text { Dulyovo } & \text { (Likino- } \\
\text { Dulyovo) } & \\
\end{array}$ & the Moscow region & Chinaware \\
\hline 28. & Gzhel & the Moscow region & Chinaware \\
\hline 29. & Kislovodsk & the Stavropol region & Chinaware \\
\hline 30. & Kasli & the Chelyabinsk region & metal handicrafts \\
\hline 31. & Zhostovo & the Moscow region & metal handicrafts \\
\hline 32. & Kazakovo & $\begin{array}{l}\text { the Nizhny Novgorod } \\
\text { region }\end{array}$ & metal handicrafts \\
\hline 33. & Dyatkovo & the Bryansk region & Crystalware \\
\hline 34. & Gus-Khrustalny & the Vladimir region & Crystalware \\
\hline 35. & Kubachi & the Republic of Dagestan & Carpet making \\
\hline 36. & Kizlyar & the Republic of Dagestan & Carpet making \\
\hline 37. & Untsukul & the Republic of Dagestan & Carpet making \\
\hline 38. & Balkhar & the Republic of Dagestan & Carpet making \\
\hline
\end{tabular}

Official existing definition: "Folk artistic crafts are one of the forms of folk art, activity on the creation of handicrafts for utilitarian and (or) decorative purposes, carried out on the basis of collective mastering and successive development of folk art traditions in a certain area in the process of creative manual and (or) mechanized labor of craftspeople" is given in the Federal Law dated January 6, 1999 No. 7-Ф3 "On folk artistic crafts "(last updated on July 29, 2017). 
It should be noted that this is a fundamental regulatory instrument that directly regulates relations in the field of folk artistic crafts in the territory of the Russian Federation.

In order to preserve folk artistic crafts under free market conditions, to protect their interests in federal and regional authorities, in 1990, on the initiative of a number of enterprises, the Association "Folk Artistic Crafts of Russia" was established.

At the present time, the Association unites more than 300 organizations of folk artistic crafts from 64 regions of the country.

Today, modern centers of folk artistic crafts are not only the basis of the souvenir industry, but also objects of educational tourism.

The main areas of folk artistic crafts are presented in Table 1.

Other types of production of handcrafts are combined in a separate sector; they include: glass-ware; bead ware made in the tradition of folk art of a particular area; dolls in Russian national costumes; patchwork-ware; garment products; musical instruments.

It should be specially noted that names of many small towns and villages of Russia are associated with well-known centers of folk art. The most famous of them are presented in table 2 .

Table 3. Museums of the Rostov region representing expositions of folk crafts, decorative and applied arts.

\begin{tabular}{|c|c|c|c|}
\hline Museum & District & Settlement & Exposition \\
\hline $\begin{array}{l}\text { the Novocherkassk Don Cossacks } \\
\text { History Museum }\end{array}$ & the Rostov region & Novocherkassk & $\begin{array}{l}\text { A traditional Cossack } \\
\text { courtyard with } \\
\text { household buildings and } \\
\text { exhibitions of Cossack } \\
\text { everyday items. }\end{array}$ \\
\hline $\begin{array}{l}\text { the Kamensk Museum of } \\
\text { Decorative and Applied Arts }\end{array}$ & the Rostov region & Kamensk-Shakhtinsky & $\begin{array}{l}\text { An exposition of } \\
\text { Cossack everyday items }\end{array}$ \\
\hline the Sholokhov National Museum & Sholokhovsky & Vyoshenskaya & $\begin{array}{l}\text { A traditional Cossack } \\
\text { courtyard with } \\
\text { household buildings and } \\
\text { exhibitions of Cossack } \\
\text { everyday items. }\end{array}$ \\
\hline $\begin{array}{l}\text { the Razdorskaya Ethnographic } \\
\text { Museum Preserve }\end{array}$ & Ust-Donetsky & Razdorskaya & $\begin{array}{l}\text { A traditional Cossack } \\
\text { courtyard with } \\
\text { household buildings and } \\
\text { exhibitions of Cossack } \\
\text { everyday items. }\end{array}$ \\
\hline $\begin{array}{l}\text { Starocherkasskaya } \\
\text { A museum preserve } \\
\text { An architectural complex - the } \\
\text { Efremov Ataman's Courtyard }\end{array}$ & Aksay & Starocherkasskaya & $\begin{array}{l}\text { A traditional Cossack } \\
\text { courtyard with } \\
\text { household buildings and } \\
\text { exhibitions of Cossack } \\
\text { everyday items. }\end{array}$ \\
\hline $\begin{array}{l}\text { the Regional Museum of Local } \\
\text { Lore }\end{array}$ & the Rostov region & Rostov-on-Don & $\begin{array}{l}\text { An exposition of } \\
\text { Cossack everyday items }\end{array}$ \\
\hline $\begin{array}{l}\text { the Volgodonsk City Museum of } \\
\text { Local Lore }\end{array}$ & the Rostov region & Volgodonsk & $\begin{array}{l}\text { An exposition of } \\
\text { Cossack everyday items }\end{array}$ \\
\hline $\begin{array}{l}\text { the Belaya Kalitva Museum of } \\
\text { Local History }\end{array}$ & the Rostov region & Belaya Kalitva & $\begin{array}{l}\text { An exposition of } \\
\text { Cossack everyday items }\end{array}$ \\
\hline $\begin{array}{l}\text { the Museum at the Aksinia } \\
\text { Semikarakorskaya Ceramics } \\
\text { Factory }\end{array}$ & the Rostov region & Semikarakorsk & $\begin{array}{l}\text { An exposition of } \\
\text { ceramics made by the } \\
\text { Aksinia Factory }\end{array}$ \\
\hline Shakhty Local History Museum & the Rostov region & Shakhty & $\begin{array}{l}\text { An exposition of } \\
\text { Cossack everyday items }\end{array}$ \\
\hline $\begin{array}{l}\text { the Cossack Museum - Quiet } \\
\text { Flows The Don }\end{array}$ & the Rostov region & Starozolotovsky & $\begin{array}{l}\text { An exposition of } \\
\text { Cossack everyday items }\end{array}$ \\
\hline
\end{tabular}


All these areas of folk crafts and handicrafts are a huge cultural heritage of Russia. The vast majority of crafts have a history that goes back centuries and is a national treasure.

Folk crafts and handicrafts are always associated with the area where the formation and further development of its various forms and types took place. As a rule, in the regions, folk crafts, handicrafts and objects of decorative and applied art are available for study in museums and exposition and exhibition complexes, and the Rostov region can illustrate it.

For example, in the Rostov region, tourists can take a look at them in the museums presented in Table 3.

The most significant of them are the Novocherkassk Don Cossacks History Museum, the Kamensk Museum of Decorative and Applied Arts and Folk Art, the Sholokhov National Museum.

The Rostov region is, first of all, the history of the Cossackdom, therefore, the Novocherkassk Don Cossacks History Museum should not go without mention. The Don Cossacks History Museum is the first museum in the Don and in the South of Russia. Its ceremonial opening took place in 1899 . Now, it is already a whole museum complex, which includes prehistoric, historical, natural history departments, a library, an archive, as well as the Ataman Palace. Memorial houses of the artists M.B. Grekov, I.I. Krylov have been established at the museum.

The Kamensk Museum of Decorative and Applied Arts is the only one museum of its kind in the region. The collection of the museum contains archaeological exhibits, paleontological, paintings, a rare holding of books and much more. The museum also presents a collection of folk art of the Don Cossackdom, the formation of which began in 1970.Now, such ancient exhibits of Cossack everyday life as a mace ornamented with silver (18th century), a cradle (19th century), a saddle (19th century) are presented there. The collection of military attributes and weapons is of particular interest. So far, there are 2500 items of the Cossackdom in the museum.

The Sholokhov National Museum is located in the Cossack stanitsa of Vyoshenskaya. The leading activity of the museum is the revival, preservation, development and popularization of traditional folk crafts and as one of the components of the culture of the Upper Don. It is interesting to note that in this museum master classes are held in various areas: pottery, willow weaving, wood carving.

Thus, considering the main types of folk crafts and of the Rostov region, we can say that the most significant are: Work of wood (in all fields), Rostov delftware, lace-making, embroidery, fabric processing, stone carving, pottery, willow weaving, metal art. For the present moment, in order to support the preservation of folk crafts, such museums as the Novocherkassk Don Cossacks History Museum, the Kamensk Museum of Decorative and Applied Arts and Folk Art, the Sholokhov National Museum are in operation. Visiting museums and master classes provides insight into the history of any folk craft, and also heightens an interest in a tourist destination.

The analysis of statistical data showed that today in Russia there are 15 main areas and more than 47 types of folk crafts, of which 11 areas are represented on the territory of the Rostov region, which is more than $70 \%$ of the total.

In addition to stationary expositions, newsworthy ethnographic events are held in the Rostov region, which are both annual and periodic. Within the framework of such events, tourists can gain a familiarity with folk crafts and items of decorative and applied arts in real life (Table 4).

Participants of folklore and ethnographic festivals act in folk costumes, the territory is decorated as a reconstruction of traditional Cossack courtyards with outbuildings and exhibitions of Cossack everyday items. 
Table 4. Newsworthy ethnographic events in the Rostov region.

\begin{tabular}{|l|l|l|l|}
\hline No & \multicolumn{1}{|c|}{ Events } & \multicolumn{1}{|c|}{ District } & \multicolumn{1}{|c|}{ Settlement } \\
\hline 1. & Ethnographic Cossackdom Festival & Aksay & $\begin{array}{l}\text { Elizavetinska } \\
\text { ya }\end{array}$ \\
\hline 2. & $\begin{array}{l}\text { the ethnographic Cossack folklore festival - } \\
\text { There is Nothing Free Like the Don }\end{array}$ & Azov & $\begin{array}{l}\text { Starocherkass } \\
\text { kaya }\end{array}$ \\
\hline 3. & $\begin{array}{l}\text { the Christmas in Razdorskaya Ethnographic } \\
\text { Festival }\end{array}$ & Ust-Donetsky & Razdorskaya \\
\hline 4. & $\begin{array}{l}\text { the Christmastide in Razdory Ethnographic } \\
\text { Festival }\end{array}$ & Ust-Donetsky & Razdorskaya \\
\hline 5. & the Christmas in the Don Ethnographic Festival & Ust-Donetsky & Razdorskaya \\
\hline 6. & the Christmas Carol Ethnographic Festival & Ust-Donetsky & Razdorskaya \\
\hline 7. & the Cossack Day Ethnographic Festival & Ust-Donetsky & Razdorskaya \\
\hline 8. & the Don Wine Ethnographic Festival & Tsimlansk & $\begin{array}{l}\text { Tsimlansk, } \\
\text { Novotsimlyan } \\
\text { skaya }\end{array}$ \\
\hline 9. & Ethnographic Sholokhov Spring Festival & Sholokhovsky & Vyoshenskaya \\
\hline
\end{tabular}

The list of newsworthy ethnographic events and festivals needs to be expanded by developing new events of both national and regional scale. So, for example, a Stanitsta (Khutor, Village) Day, Harvest Festival, Festival of Folk Crafts, Festivals of Craftspeople, etc. can be held annually.

The most famous folk crafts of the Rostov region contributed to its reputation not only in Russia, but also abroad. In Russia, wood has always been the main material for folk art.In mythology, it epitomized the universe.

Work of wood has different areas. Wood carving is the most famous of them. Molded and Abramtzevo-Kudrino carving is mainly applied. Wood carving is the most common craft because some processing methods does not require special equipment. Hence the variety of types and subtypes of this craft.

The next area of work with wood is average - this is pokerwork. The Rostov region is famous for its wooden trenchers with openwork poker-painting.

In many villages of the Rostov region there are houses decorated with carved wooden ornaments and shutters. This is another area of wood carving.

The most beautiful kind of folk crafts is lace-making. Lace is woven of silk or cotton thread, which gives them special elasticity and attractiveness. Such products are used as an addition to clothing, as well as curtains and pillow covers. The appearance of such lace is more like a frosty pattern, which is depicted on frozen glass.

As for embroidery, Rostov embroidery has a special style. It is called colored perevit. This embroidery is made on an inverted net. The columns on the net are tightly wrapped with threads of different colors. Then, changing the color of the threads, they perform various patterns. As a rule, needlewomen of textile printing first made a painted design on any kind of fabric and then, using a special needle, they insert a thread, according to the pattern.

In the Rostov region, stone carving, as a type of folk craft, can rather be called homecraft. During various excursions dedicated to this folk craft, you can purchase a brooch, earrings, caskets, buttons, etc. in which local craftsmen show all the beauty of the stone.

Russia is considered to be one of the countries where the blacksmith craft originated. In the Rostov region, this type of art work is quite popular. It is difficult to find a village in the region that does not have a blacksmith. But local blacksmiths not only bend horseshoes and 
shoe horses; they create various items of extraordinary beauty. Today the tourist route "Blacksmiths of Rostov" is very popular; tourists are offered not only to see how metalware is made, but also to try themselves as a blacksmith.

Rostov delftware is a rather widespread craft in the region. It is associated with manufacturing items of baked clay. The region is famous for its earthenware, painted in folk styles.

In 1972, the Aksinia factory, which manufactures delftware, has been established in the Rostov region. Delftware is a type of ceramic composition, for the manufacture of which it is required to be burned at a low temperature. These items contain all the beauty of the Cossack region, its customs and traditions. Earthenware with openwork painting is especially popular.

Thus, it can be said that the most famous folk crafts in the Rostov region include: work of wood (in all fields), Rostov delftware, lace-making, embroidery, fabric processing, stone carving, pottery, willow weaving, metal art, earthenware, and jewelry art.

Considering folk crafts as a growth driver of educational tourism, we mean cultural and educational tours, which should include visits to museums of folk crafts, decorative and applied arts. It can be assumed that folklore and ethnographic festivals may be of particular interest to tourists traveling for educational purposes.

\section{Discussion}

Folk crafts, decorative and applied arts are always associated with the territory where the formation and further development of their various forms took place, and this, as a rule, is a rural area.

Thus, the popularization of folk crafts, decorative and applied arts is not only a growth driver of educational tourism, but also a tool for generating employment and new opportunities for small and medium rural enterprises.

Prospects for the development of educational tourism require not only the preservation, but also the revival of folk arts and crafts, that provide the market with souvenirs closely related to a specific tourist center.

The inclusion of folk crafts, decorative and applied arts in the programs of educational tours will create innovative tourist routes that will extend the tourist season and contribute to the sustainable development of rural areas.

Analyzing the types of well-known folk crafts presented in various towns and villages of Russia, it can be concluded that many of them are classified as classical and popular.

So, for example, Rostov enamel miniature, Palekh miniature, Zhostovo painting, Gzhel and other folk crafts are now a kind of world famous brands, which are produced by enterprises. Folk crafts, handicrafts and items of decorative and applied arts are widely represented both in state and private museums. The most famous are: the Nizhny Tagil Museum of the Trencher Art History, which has the status of a federally significant cultural heritage; the All-Russian Decorative Art Museum in Moscow and the Kamensk Museum of Decorative and Applied Arts in Kamensk-Shakhtinsky (Rostov region), which have the status of a regionally significant cultural heritage; the State Museum of Oriental Art in Moscow, which has the status of a cultural heritage of the peoples of the Russian Federation.

State museums: the Nizhny Novgorod Region Museum of Arts and Crafts History in Nizhny Novgorod, the Lace Museum in Vologda; the Tavolga Delftware Museum in the village of Verkhnie Tavolgy (Sverdlovsk region).

Private museums: the Samovar and Bouillotte Museum in the Tula region; the Spoon Museum in Vladimir; the World of Caskets in Stavropol; the Fabergé Museum in SaintPetersburg. 
However, as it was previously said, today almost all regions of Russia, municipal formations and even separate tourist localizations have their own, sometimes small, but unique folk artistic crafts. It is the uniqueness that makes it possible to arrange exclusive educational tours.

Therefore, they should be promoted and popularized.

These are the ways to do it:

- in offices of tour operators and sightseeing tour agencies (to include information and photo materials on folk crafts and handicrafts in leaflets and prospects);

- to arrange souvenir shops in exhibition complexes, at regional fairs, competitions and festivities, folklore festivals and literary and ethnographic fests;

to organize specialized thematic trade fairs of folk crafts and handicrafts (including those within the framework of annual specialized events, such as Rostov the Hospitable);

- to organize online exhibitions (for example, as a structural element of the Know Ours online exhibition);

- to invite masters and organize master classes as a part of city mass events;

- when holding large conferences, congresses and forums, to include souvenirs in handouts for business tourists;

- to arrange exhibitions in local lore, history, and art museums;

- to develop thematic excursions, directly in the places where folk crafts are located (at enterprises, workshops, artels, art schools, clubs, etc.);

- in trade enterprises (sale of handicrafts with information about the place of their production, the possibility and time of visiting, etc.);

- by organizing joint exhibitions and fairs with world famous brands such as Rostov enamel miniature, Palekh miniature, Zhostovo painting, Gzhel in the Rostov region;

- by including annual exhibitions and fairs of folk crafts, decorative and applied arts in the event calendar of the Rostov region;

- by keeping a craft register;

- by popularizing in the media and on the Internet;

- by posting information in tourist information centers.

It is necessary to create clusters of folk crafts, decorative and applied arts in Russia as a whole and in certain regions in particular, including the Rostov region. These clusters will contribute to formation of a brand and upgrading of the image component of the tourist region; they will become the basis for laying down tourism development programs for each municipal district with a focus on folk crafts, which can act as a growth driver of educational tourism.

\section{Conclusions}

Thus, this study brings us to the following conclusions.

Folk crafts, decorative and applied arts can be considered as a driver for the development of educational tourism, both in rural and urban areas.

The revival of folk crafts, decorative and applied arts is an important part of national culture, which combines both the field of folk art and the industry. Therefore, tourism is becoming the essential branch in preserving and developing arts and crafts.

The development of folk crafts, decorative and applied arts requires an active support of regional and local authorities. It is necessary to develop programs and projects of comprehensive development and revival of folk crafts, decorative and applied arts, as well as of strategy for the development of folk crafts, decorative and applied arts. 
Considering folk crafts, decorative and applied arts as a growth driver of educational tourism, it can be said that the Rostov region has the necessary potential, which in the future can attract additional tourist flows to the region.

Listed locations, newsworthy ethnographic events and ways to popularize folk crafts, decorative and applied arts can become not only a promising growth driver of educational tourism, but also have a positive effect on the formation of priority areas of investment policy in the region, and will also contribute to a rise in quality of life of local population and new job formation.

\section{References}

1. A. Liu, D. C. Wu, Annals of Tourism Research, 76, 253-265 (2019)

2. S.-T. Liu, Journal of Destination Marketing \& Management, 16 Article 100432 (2020)

3. E. D. Santa, S. A. Tiatco, Tourism Management Perspectives, 31, 301-309 (2019)

4. A. Z. Zakaria, I. H. Salleh, M.S. Abd Rashid, Procedia - Social and Behavioral Sciences, 15316, 298-307 (2014)

5. W. C. Hunter, Annals of Tourism Research, 82, Article 102919 (2020)

6. M.-N. Văidianu, O. Pavel, I.-E. Călin, Procedia - Social and Behavioral Sciences, 12219, 105-109 (2014)

7. X. Yu, H. Xu, Journal of Destination Marketing \& Management, 13, 39-50 (2019)

8. C. Wei, S. Dai, H. Xu, et al., Journal of Hospitality and Tourism Management, 43, 241-249 (2020)

9. E. Chibir, T. Shirko, Procedia Economics and Finance, 26, 183-187 (2015)

10. M. Haigh, Tourism Management, 81, Article 104166 (2020)

11. F. Thompson, K. Hannam, K. Petrie, Annals of Tourism Research, 39 (1), 336-360 (2012)

12. Z. Shtudiner, G. Klein, M. Zwilling, J. Kantor, Annals of Tourism Research, 74, 17-32 (2019)

13. C. Anastasiadou, S. Vettese, Tourism Management, 71, 428-442 (2019)

14. B. Klein, International Encyclopedia of the Social \& Behavioral Sciences (Second Edition), 280-284 (2015)

15. P. Hayward, S. Kuwahara, Journal of Marine and Island Cultures, 3 (1), 20-30 (2014)

16. T.-H. Tsai, C.-M. Chen, Tourism Management Perspectives, 30, 208-219 (2019)

17. N.V. Yakovenko, Contemporary issues in service and tourism, 9 (4), 62-70 (2015)

18. N.V. Yakovenko, Contemporary issues in service and tourism, 10 (3), 50-53 (2016)

19. G.V. Ganshina, N.V. Chaus, Contemporary issues in service and tourism, 2, 76-86 (2012)

20. G.M. Samostroenko, Regional economy: principles and practices. Tourism and recreation zones1, 19-23, (2012)

21. M.A. Sarancha, S.L. Yakimova, Contemporary issues in service and tourism, 9 (4), 44-49 (2015)

22. D.A. Amandzholova, Service plus, 2, 30-37, (2013)

23. A.V. Shestakova, Bulletin of Immanuel Kant Baltic Federal University. Natural sciences, 1, 104-111, (2008) 
24. V. Aleksunin, M. Chernaya, Norwegian Journal of development of the International Science, 20, 8 - 14 (2018)

25. A. S. Vergori, S. Arima, Tourism Management, 78, Article 104058 (2020)

26. L.N.Kazmina, V.S.Makarenko, V.V.Provotorina, International Journal of Economics and Business Administration, 7, 510-520 (2019) doi:10.35808/ijeba/297

27. L. Kazmina, V.Makarenko, V.Provotorina, E.Shevchenko, E3S Web of Conferences, 175, $10001(2020)$ 